\title{
Effect of Planting Density and Harvest Interval on the Leaf Yield and Quality of Moringa (Moringa oleifera) under Diverse Agroecological Conditions of Northern South Africa
}

\author{
M. P. Mabapa, ${ }^{1}$ K. K. Ayisi, ${ }^{1,2}$ and I. K. Mariga ${ }^{1}$ \\ ${ }^{1}$ Department of Plant Production, Soil Science and Agricultural Engineering, University of Limpopo, Private Bag Box X1106, \\ Sovenga 0727, South Africa \\ ${ }^{2}$ Risk and Vulnerability Science Centre, University of Limpopo, Private Bag Box X1106, Sovenga 0727, South Africa
}

Correspondence should be addressed to M. P. Mabapa; paulina.mabapa@ul.ac.za

Received 4 July 2017; Accepted 16 November 2017; Published 31 December 2017

Academic Editor: Yong In Kuk

Copyright @ 2017 M. P. Mabapa et al. This is an open access article distributed under the Creative Commons Attribution License, which permits unrestricted use, distribution, and reproduction in any medium, provided the original work is properly cited.

\begin{abstract}
Smallholder livestock farmers who depend on natural communal grazing lands are particularly vulnerable to climate change as well as to food insecurity and should be encouraged to grow drought-tolerant fodder crops. Moringa oleifera is a highly valued plant, due to its exceptionally high nutritional content. This study was conducted at two experimental sites in the Limpopo province of northern South Africa to evaluate for the first time the effect of plant density and cutting interval on biomass production and chemical composition of moringa grown under two diverse climatic conditions. Four different planting densities $(435,000,300,000$, 200,000, and 100,000 plants/ha) were arranged in a randomized complete block design and experimental samples were replicated four times. Data for biomass and gravimetric soil moisture content were collected each time the plants reached a height of $50 \mathrm{~cm}$. Harvested leaves were analysed for chemical composition. An increase in the plant density led to elevated biomass production at both study locations, ranging between 527 and $2867 \mathrm{~kg} / \mathrm{ha}$. Moringa is capable of meeting all nutrient requirements of livestock depending on harvest time and location.
\end{abstract}

\section{Introduction}

Agriculture makes vital contributions to the living conditions of rural communities in South Africa as livestock and crop production are their main sources of livelihoods. Farmers rear livestock and mainly depend on natural grazing land because of their inability to purchase feed supplements or to grow fodder crops under intensive management systems where water and fertilizer inputs are unaffordable. However, the prospect of climate change poses a serious threat to food security and feed supply, whereby some farmers will lose their livestock owing to a shortage of fodder. Changes in temperature and rainfall patterns due to drought, excessive heat with temperatures which can rise beyond $30^{\circ} \mathrm{C}$ on three or four consecutive days, and unpredictable rainfall and strong wind are the major threats to the production of food by smallholder farmers in South Africa [1]. More resilient food crops therefore need to be investigated to cope with changing weather conditions.

The Limpopo province of northern South Africa falls largely within a semiarid zone so that farmers should be encouraged to grow fodder crops which are drought-tolerant and are also capable of producing enough yield during periods of drought. According to Maponya and Mpandeli [2], drought and extreme temperatures are already causing serious problems in the province, forcing farmers in some areas to sell their livestock due to lack of feed. These drought conditions are not limited to Limpopo alone but to South Africa as a whole [2]. Lack of sufficient and highquality fodder, mainly during the dry seasons in tropical and subtropical areas in particular, has increased the need to provide supplementary fodder to sustain farm animals [3].

Fodder trees such as Acacia spp., Sesbania sesban, Dalbergia sissoo, and Moringa oleifera are recognised throughout 
Africa for their ability to supplement livestock feed during times of intense drought [4]. These species are capable of producing more foliage with high contents of digestible and other essential nutrients as high-quality forage supplement for livestock relative to herbaceous species [5]. The majority of forage trees have the ability to retain their leaves even during dry seasons $[4,6]$. Relying on herbaceous plants as drought feed is particularly challenging because they become unavailable due to hot weather and associated harsh conditions including water shortage [4] and sometimes veld fires.

Moringa oleifera Lam. is a remarkably fast growing tree and highly valued plant due to its exceptional nutritional content [5]. It grows in many tropical and subtropical regions $[7,8]$. Countries and areas such as India, the Philippines, Hawaii, and countries in Africa use the tree, mainly because it has a wide range of medicinal uses and due to the relatively high nutritional value of its leaves, fruit, flowers, and immature pods compared with other food crops [810]. Nouman et al. [11] reported that moringa can be grown under harsh conditions in hot, humid, and dry tropical and subtropical regions. An exception is areas that experience waterlogging. The tree can produce substantial nutritional quality even under marginal conditions.

The great potential benefits mean that there is a need to critically assess harvesting practices that optimise biomass production of moringa under different agroecological conditions. Planting density and frequency of cutting have been identified as critical management practices that affect biomass yield and leaf quality [12-14]. The main objective of the study reported here was to establish, for the first time, the effect of planting spacing and cutting interval on aboveground biomass production and nutritional quality of Moringa oleifera under different climatic conditions in two study sites in northern South Africa.

\section{Materials and Methods}

2.1. Study Area. The study was conducted from December 2014 to March 2016 under two different agroecological conditions, namely, the University of Limpopo experimental farm known as Syferkuil and the Itemeleng Ba Makhutjwa Farming Cooperative known as Ofcolaco. The two sites will be referred to by their commonly known names in this article. Syferkuil (coordinates: $23^{\circ} 50^{\prime} \mathrm{S} ; 29^{\circ} 0^{\prime} \mathrm{E}$ ) is situated about $35 \mathrm{~km}$ southeast of Polokwane City at an elevation of $1230 \mathrm{~m}$ above sea level. The climate of this area is classified as semiarid with an annual average rainfall of 400-500 mm occurring mostly in the summer months. The area experiences an average annual minimum temperature of $12.6^{\circ} \mathrm{C}$ and maximum temperature of $25.0^{\circ} \mathrm{C}$ during the crop-growing season [15]. The soil at the study site is classified as Hutton [16]. Soil structure is granular with a good infiltration rate and has an effective depth of $90 \mathrm{~cm}$ [17]. Ofcolaco is located $43 \mathrm{~km}$ southeast of the town of Tzaneen (coordinates: $24^{\circ} 4^{\prime} 60^{\prime \prime} \mathrm{S}$ and $30^{\circ} 22^{\prime} 0^{\prime \prime} \mathrm{E}$ ); the area receives an average annual rainfall of $700 \mathrm{~mm}$ mainly in the summer months of October to March. It experiences an average annual minimum temperature of $15^{\circ} \mathrm{C}$ and annual average maximum temperature of $28.1^{\circ} \mathrm{C}$, at an elevation of $626 \mathrm{~m}$ above sea level [18]. The soil is classified as Hutton and has good drainage characteristics, with the effective soil depth of $120 \mathrm{~cm}$ containing highly weathered manganese concretions at $100 \mathrm{~cm} \mathrm{[17].}$

2.2. Experimental Design and Management. Prior to moringa planting, the soil was ploughed followed by disking and harrowing. Moringa seeds were soaked in cold water overnight and planted at a depth of $4 \mathrm{~cm}$ in the soil, with two seeds placed per hole. After six weeks, the plants were thinned to leave only one healthy tree per station. The field trial was laid out as a randomized complete block design (RCBD). Plant densities were examined at four levels, namely, 435,000, 300,000, 200,000, and 100,000 plants/ha. Experimental samples were replicated four times per treatment. Irrigation was applied for four hours twice a week using a sprinkler irrigation system until the sixth week to encourage good tree establishment, after which the study was allowed to run under rainfed conditions. Weather data were collected throughout the trial from Syferkuil and at a weather station located less than $10 \mathrm{~km}$ from the experimental area in Ofcolaco. Weather results are presented in Figure 1. During the course of the study, the experimental units were well maintained by removing weeds manually by hand hoe. Insect pest and plant disease incidences were not observed during the study. To reflect the financial constraints experienced by the local smallholder farmers, no fertilizer was applied in this study. The initial physical and chemical properties of the soils under test were determined at a depth of $0-30$ and $30-60 \mathrm{~cm}$ using an auger to identify their nutrient status (Table 1).

2.3. Plant Sampling Procedure. Aboveground biomass was harvested when $90 \%$ of the plants within an experimental unit reached a height of at least $50 \mathrm{~cm}$ measured from ground level to the tree apex. A net plot of $2.4 \mathrm{~m}^{2}$ was used for data collection. Biomass harvesting was carried out manually using pruning shears at a uniform height of $10 \mathrm{~cm}$ above ground, throughout the experiment, whenever plants had reached $50 \mathrm{~cm}$ cutting height. The average height of plants within an experimental unit was estimated by measuring the heights of five randomly selected plants in each net plot prior to harvesting. Measurements were made between ground level and the tip of the uppermost leaf of the plant [13]. During each harvest, soils were sampled at depths of $0-15,15-30$, and $30-45 \mathrm{~cm}$ to determine gravimetric soil moisture percentage. An auger was used to sample the soils according to depth; zip-lock plastic bags were used to retain soil moisture before measurement. Soil moisture was determined immediately after sampling using a battery-operated top loading weighing balance (RADWAG, W/C6/12/C1/R model). Soils were placed in aluminium drying pans and dried in an oven (Scientific Oven Economy, 240 litres, model 223 ) for 24 hours at a temperature of $105^{\circ} \mathrm{C}$. Gravimetric soil moisture percentage was determined when the soil samples had reached a constant weight, using a method described by Black [19]. The total aboveground fresh biomass was shadedried at room temperature for 72 hours to ease separation of leaves and stems. Shoots were further oven-dried for 48 hours at $65^{\circ} \mathrm{C}$ until the samples had reached constant dry weight. 
TABLE 1: Physical and chemical properties of soil at the experimental sites.

\begin{tabular}{|c|c|c|c|c|c|c|}
\hline \multirow{3}{*}{ Soil properties } & \multicolumn{3}{|c|}{ Syferkuil } & \multicolumn{3}{|c|}{ Ofcolaco } \\
\hline & \multicolumn{6}{|c|}{ Soil depth $(\mathrm{cm})$} \\
\hline & $0-30$ & $30-60$ & Average & $0-30$ & $30-60$ & Average \\
\hline $\mathrm{pH}(\mathrm{KCl})$ & 6.54 & 6.98 & 6.8 & 5.13 & 5.22 & 5.2 \\
\hline Clay (\%) & 30 & 34 & 32 & 30 & 31 & 30.5 \\
\hline Org. C (\%) & 0.8 & 0.5 & 0.7 & 1.4 & 1.1 & 1.3 \\
\hline Total N (\%) & 0.06 & 0.04 & 0.1 & $<0.05$ & $<0.05$ & $<0.1$ \\
\hline $\mathrm{P}(\mathrm{mg} / \mathrm{L})$ & 10 & 15 & 12.5 & 8 & 3 & 5.5 \\
\hline $\mathrm{K}(\mathrm{mg} / \mathrm{L})$ & 353 & 283 & 318 & 212 & 105 & 158.5 \\
\hline $\mathrm{Ca}(\mathrm{mg} / \mathrm{L})$ & 1139 & 1487 & 1313 & 646 & 756 & 701 \\
\hline $\mathrm{Mg}(\mathrm{mg} / \mathrm{L})$ & 868 & 878 & 873 & 178 & 153 & 165.5 \\
\hline $\mathrm{Zn}(\mathrm{mg} / \mathrm{L})$ & 1.1 & 1.2 & 1.2 & 1.9 & 0.6 & 1.3 \\
\hline $\mathrm{Mn}(\mathrm{mg} / \mathrm{L})$ & 5 & 3 & 4 & 41 & 45 & 43 \\
\hline $\mathrm{Cu}(\mathrm{mg} / \mathrm{L})$ & 5 & 4 & 4.5 & 6 & 5.4 & 5.7 \\
\hline
\end{tabular}

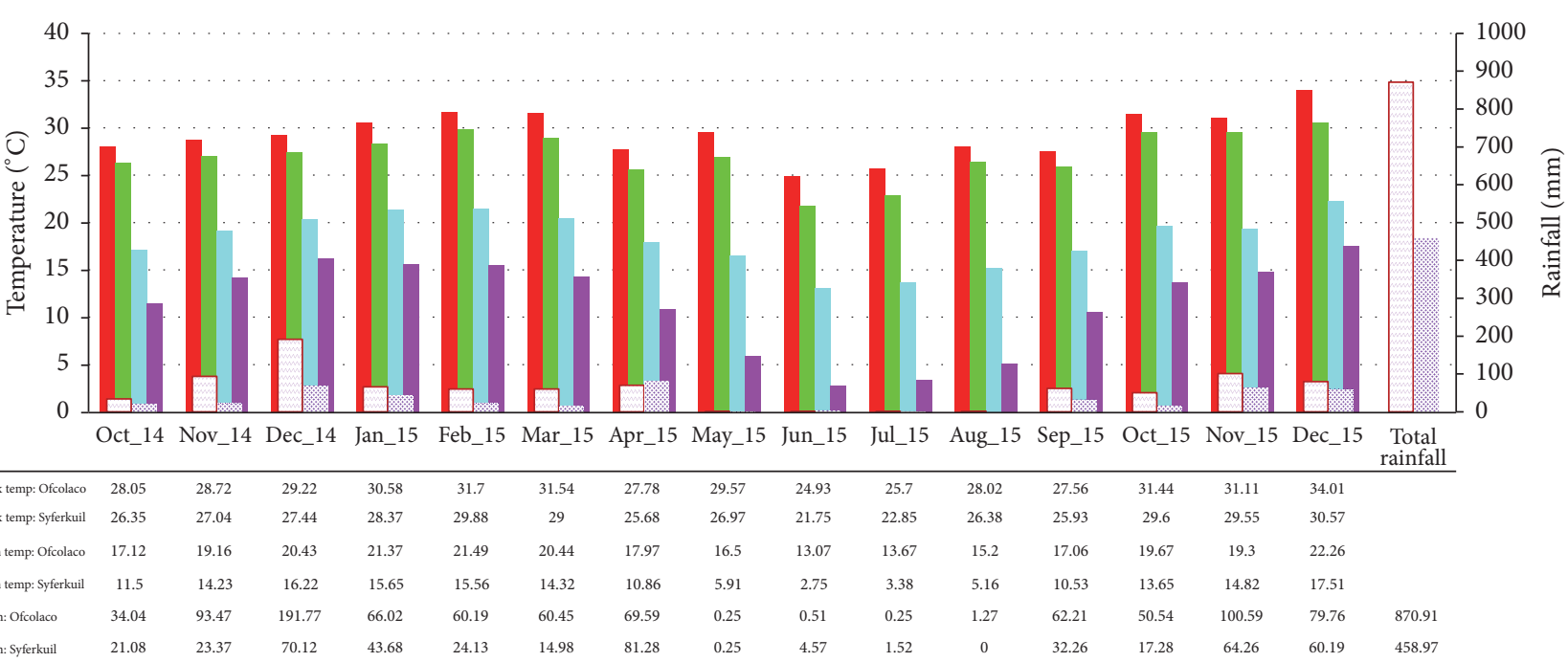

FIGURE 1: Weather data recorded during the 2014 and 2015 field trials at Syferkuil and Ofcolaco.

The variables evaluated included total shoot dry matter yield (TSDMY); a sample of a fine fraction of leaves was taken for chemical analysis.

2.4. Nutrient Determination. Moringa leaf samples, dried at room temperature $\left(24^{\circ} \mathrm{C}\right)$ for 72 hours, were ground to pass through a $2 \mathrm{~mm}$ sieve; and $10 \mathrm{~g}$ of a fine fraction was used to determine their chemical composition. Crude protein was determined using the Kjeldahl method [20]. Other minerals such as $\mathrm{P}, \mathrm{K}, \mathrm{Ca}, \mathrm{Mg}, \mathrm{Mn}$, and $\mathrm{Zn}$ were determined using atomic absorption [21].

2.5. Statistical Analysis. Data were subjected to analysis of variance using Statistix 10.0 to determine the effect of planting density and harvest frequency on measured variables. Where significant $F$-values from the treatment effect were found, means were separated by least significant difference (LSD) at a probability level of 0.05 . Linear correlation and regression analyses were performed using Microsoft Excel to determine the relationship between cutting frequency and biomass yield.

\section{Results}

3.1. Effect of Plant Density on Biomass Production. The results of cutting interval and plant density on biomass production at the two study sites are indicated in Figure 2. It was observed that the increase in planting density led to increase in plant biomass at both locations. Planting density had a significant influence on biomass production at both Syferkuil and Ofcolaco. It took longer time to attain fourth harvest at Syferkuil than at Ofcolaco. At Syferkuil, the time intervals between harvests 1 and 2, 2 and 3, and 3 and 4 were 92, 229, and 64 days after each harvest, respectively. At Ofcolaco, the corresponding intervals were 44, 181, and 85 days.

At Syferkuil, biomass across the densities ranged from 735 to $1430 \mathrm{~kg} / \mathrm{ha}$, from 892 to $1322 \mathrm{~kg} / \mathrm{ha}$, from 611 to $943 \mathrm{~kg} / \mathrm{ha}$, and from 1382 to $2039 \mathrm{~kg} /$ ha for harvests $1,2,3$, and 4, respectively. At Ofcolaco, the corresponding biomass values for the 

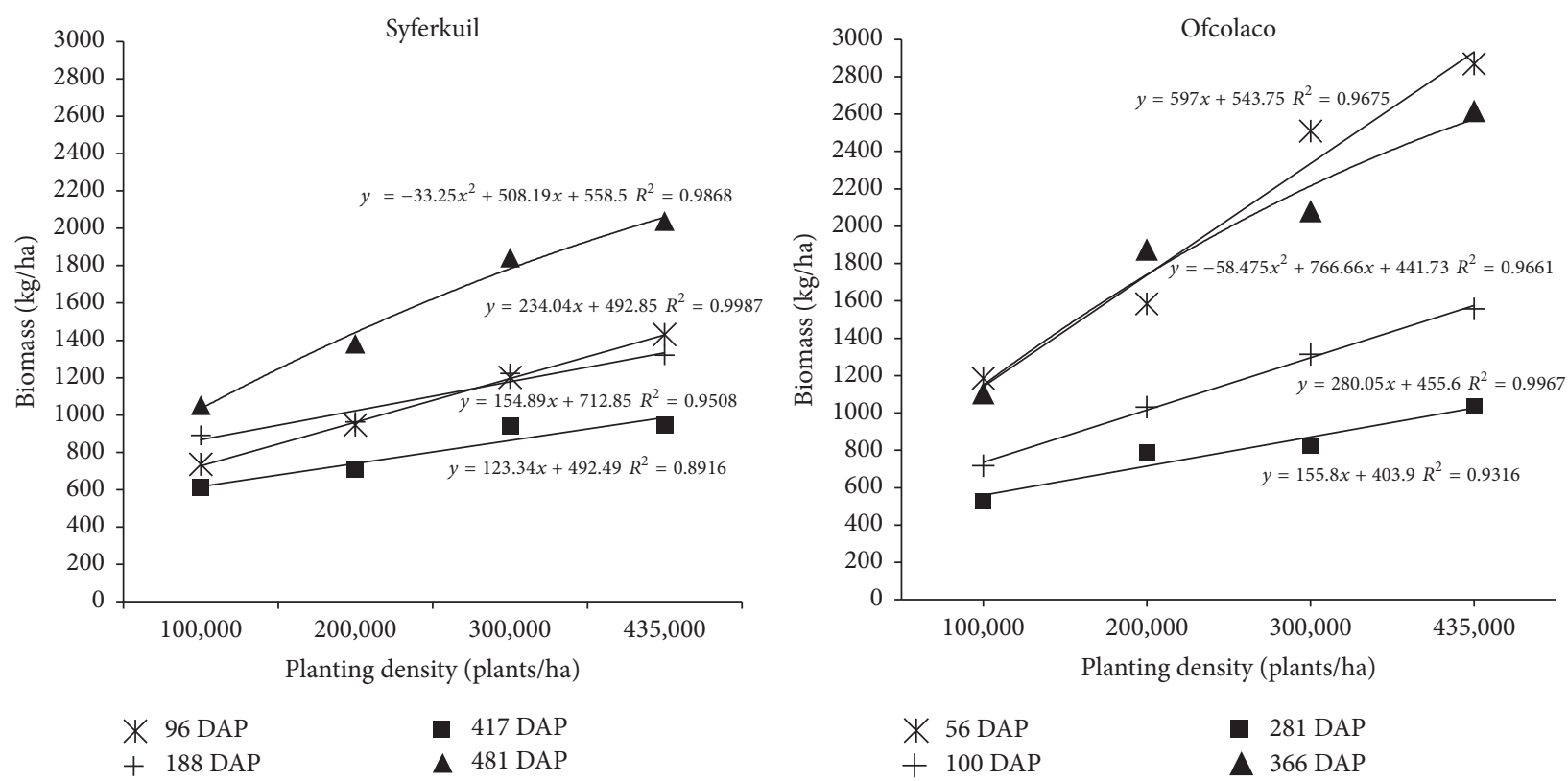

FIGURE 2: Effect of planting density on moringa biomass production at four harvest intervals at both study sites across the four seasons. DAP: days after planting.

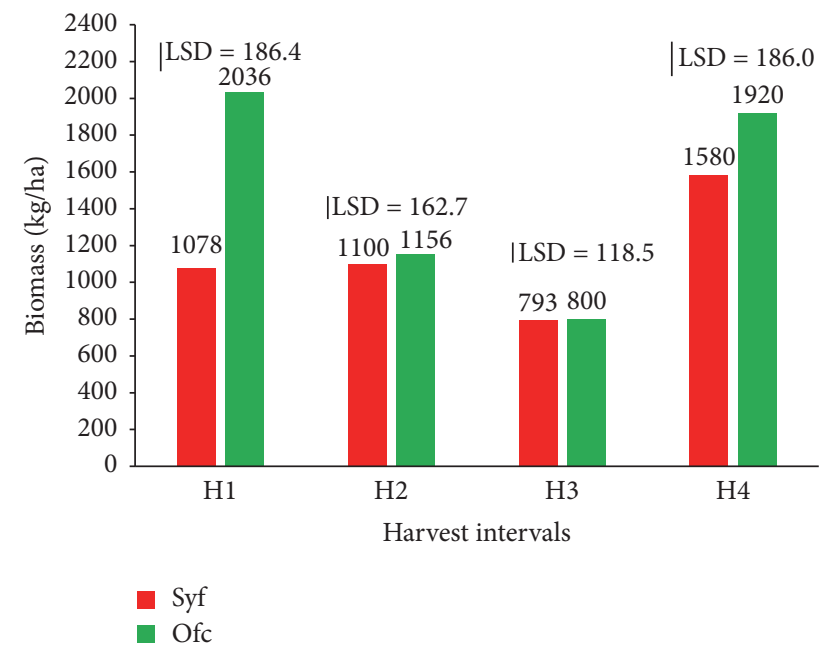

FIGURE 3: Biomass production of moringa at four harvest intervals at Syferkuil and Ofcolaco across the four seasons irrespective of the planting density. LSD: least significant difference. H1: harvest 1; H2: harvest 2; H3: harvest 3; H4: harvest 4; Syf: Syferkuil; Ofc: Ofcolaco.

four harvests ranged between 1185 and $2867 \mathrm{~kg} / \mathrm{ha}$ (harvest 1), between 718 and $1557 \mathrm{~kg} / \mathrm{ha}$ (harvest 2), between 527 and $1035 \mathrm{~kg} / \mathrm{ha}$ (harvest 3), and between 1106 and $2618 \mathrm{~kg} / \mathrm{ha}$ (harvest 4). At both locations, a higher planting density resulted in a greater biomass yield from all harvests (Figure 2).

Biomass production did not differ $(P \leq 0.05)$ between locations at harvests 1 and 2 but was different at harvests 1 and 4 (Figure 3). Where significance was observed, the biomass production at Ofcolaco was higher than at Syferkuil.

It was observed that, at both study sites, diverse weather conditions might have affected the time to harvest the plants.
Figure 1 shows that both temperature and rainfall at Syferkuil were correspondingly lower than at Ofcolaco.

3.2. Effect of Moisture on Biomass Production of Moringa. Gravimetric soil moisture percentage at the time of the four harvests at both locations is presented in Figure 4. Based on a regression analysis, a significant quadratic relationship of over $90 \%$ between gravimetric soil moisture and harvest intervals was observed across all planting densities. At Syferkuil, the moisture percentage was higher during the first and second harvests at the relatively high planting densities of 435,000 and 300,000 plants/ha and also showed a decreasing trend with reduction in plant density. However, at the third and fourth harvests, the moisture content dropped to a constant level at different planting densities. At Ofcolaco, an increase in the number of plants per unit area was associated with increased soil moisture content until the third harvest. Moisture contents remained similar among planting densities during the fourth harvest at both study sites.

\subsection{Effect of Planting Density and Cutting Frequency on Chem-} ical Composition of Moringa Leaves. The effect of planting density and harvest interval on the nutritional quality of moringa leaves at the two study sites is presented in Table 2. At Syferkuil, plant density and cutting interval did not influence crude protein (\%), Ca, Mg, K, P, and $\mathrm{Zn}$ content. However, a decrease in iron content and an increase in manganese content were observed during the third harvest across all planting densities (Table 2). At Ofcolaco, cutting interval had a negative influence on the nutritional quality of moringa leaves mainly at harvests 3 and 4 . The following chemical properties were affected by cutting interval: crude protein, $\mathrm{K}$, $\mathrm{P}, \mathrm{Fe}, \mathrm{Mn}$, and $\mathrm{Zn}$ content. At harvests 1 and 2, the chemical 

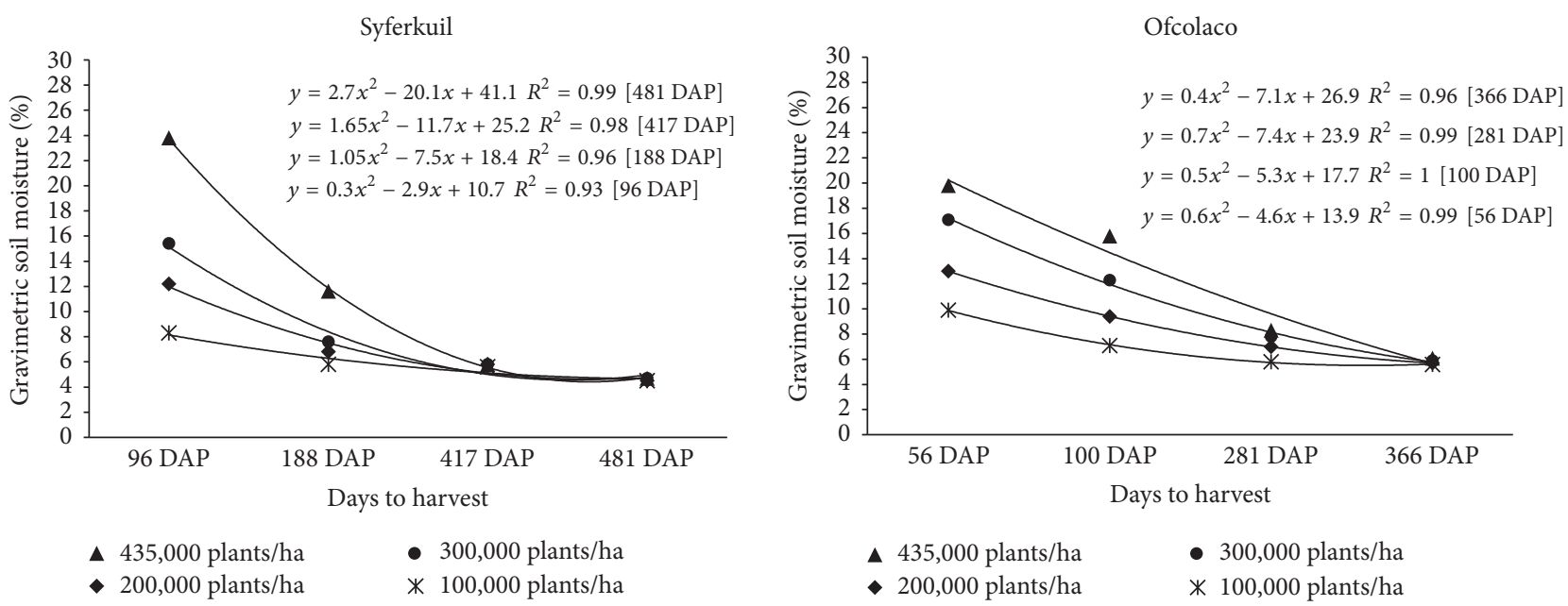

FIGURE 4: Influence of planting density on gravimetric soil moisture percentage at different harvest intervals at Syferkuil and Ofcolaco across all seasons. Note. DAP: days after planting.

compositions were generally higher than later, although at harvests 3 and 4 these fell markedly (Table 2).

\section{Discussion}

4.1. Effect of Plant Density on Biomass Production. This study demonstrated that the greater the plant density the higher the total aboveground dry biomass production of moringa across harvests times and at both locations, although the effect on plant height at each harvest was not significant. Nouman et al. [4], Amaglo et al. [13], and Fadiyimu et al. [22] focused their work on biomass production and cutting frequencies at a given number of days to harvest. Our study was different from theirs in the sense that, in all four treatments, the trees were cut to a uniform height of $10 \mathrm{~cm}$ above ground level when they had reached the same height of $50 \mathrm{~cm}$. It took 481 days after planting to reach the fourth harvest at Syferkuil compared to 366 days at Ofcolaco and this is primarily due to variation in weather, particularly minimum temperature (Figure 1). At both study sites, the time taken to reach the third harvest was longer than the other intervals. This could be the result of the cold weather experienced in Limpopo between May and August (Figure 1). The prevailing low temperature and dry conditions negatively affected biomass yield of the plants in the period to harvest 3 at both locations. Other findings support the results of this study; for example, drought or low rainfall conditions resulted in stunted regrowth and reduced total aboveground dry matter yield, whereas dry matter productivity was greater during the rainy season $[9,12,22]$. A study by Amaglo et al. [13], on the effect of spacing and harvest frequency on the growth and leaf yield of moringa, indicated a significant difference $(P<0.05)$ in shoot yield per hectare due to density but not due to frequency of harvesting. Their results concurred with findings from this study such that the closest experimental spacing of $5 \times 5 \mathrm{~cm}$ between the plants produced the greatest leaf biomass yield ranging between 10 and $30 \mathrm{t} / \mathrm{ha}$; medium spacing of $5 \times 10 \mathrm{~cm}$ and relatively wide spacing of $5 \times 15 \mathrm{~cm}$ resulted in the lowest yield of 3-12 t/ha. Nouman et al. [4] found that cutting frequency and height significantly affected both fresh and dry moringa biomass at $P<0.05$; maximum fresh biomass was obtained in the hot rainy season when the plants were harvested at $30 \mathrm{~cm}$ above ground level. Another study, by Goss [23], aimed at determining the effect of moringa planting density on biomass accumulation and leaf yield, indicated that increasing the density up to 197,528 plants/ha raised the plant dry matter yield. The highest value of $3.4 \mathrm{t} /$ ha was achieved. These findings are in agreement with results from this study, in that increasing planting density led to increased biomass yield at both locations (Figure 2). This study also showed that climatic and environmental factors played a major role in biomass production of moringa. The crop produced a reasonable biomass yield, bearing in mind that the plants did not receive any supplementary growth inputs such as irrigation and fertilization. Indeed, this study was conducted to simulate smallholder farming condition in Limpopo, which is characterised by low-resource conditions. Comparing results from this study with those of Mendieta-Araica [9], the latter reported that, under dry conditions, available $\mathrm{P}$ and $\mathrm{K}$ in the soil can maintain a relatively high biomass yield over time, when sufficient nitrogen fertilizer is supplied to cover the nutrients that are removed at harvest and are needed for regrowth. Amaglo et al. [13] revealed that relatively high shoot productivity may be maintained only by continuously replenishing the nutrient intake by plants from the soil by adequate application of fertilizer, preferably an organic fertilizer that is of less cost to smallholder farmers and does not have the adverse environmental and health impacts of mineral supplements. Abdullahi et al. [24] recommended that the combination of 20,000 stands per hectare and a fertilizer application rate of $200 \mathrm{~kg} \mathrm{~N}$ per hectare is the optimum one for the cultivation of Moringa oleifera for biomass production in the North-Central zone of Nigeria, where the area is characterised by hot summer temperatures and high rainfall of up to $1300 \mathrm{~mm} / \mathrm{a}$. Dania et al. [25] further reported that the application of poultry manure significantly increased the vegetative growth of this crop. 


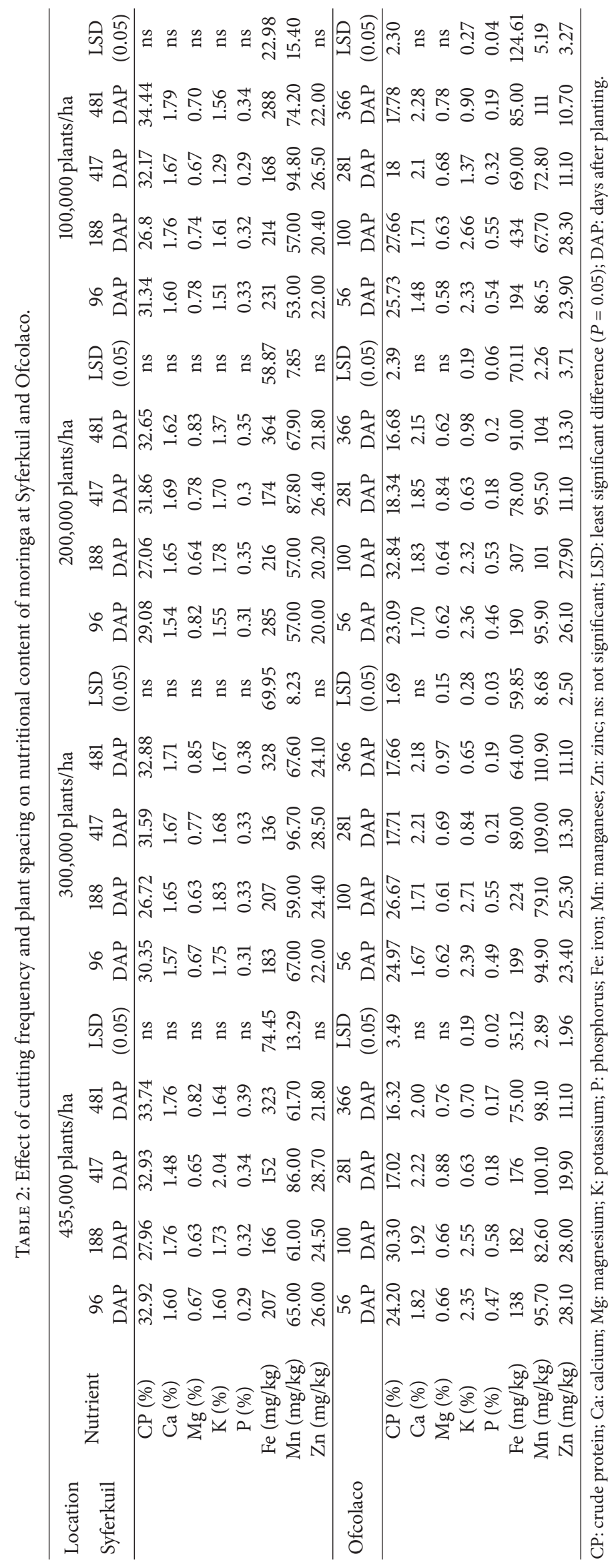


4.2. Effect of Moisture on Biomass Production of Moringa. Biomass accumulation continued to increase under favourable weather conditions of temperature and rainfall at harvests 1,2 , and 4 when the trees were pruned (Figure 1). This is an evidence that moringa can survive and produce satisfactory yields even under conditions of water limitation such as Syferkuil, where the crops experienced relatively lower total rainfall. At Ofcolaco, the yield was more than $1 \mathrm{t} / \mathrm{ha}$ at a high density of 435,000 plants/ha. Soil moisture content was greater at Ofcolaco than at Syferkuil and this could be the result of higher rainfall received at the former. Greater rainfall and relatively close plant spacing, which together reduce the rate of evapotranspiration, had an added advantage for the enhanced soil moisture at Ofcolaco (Figure 3). This study was conducted under dry-land conditions, in which plant growth and development relied on only rainfall. During the early growth stage, a higher plant density maintained higher gravimetric soil moisture at both locations (Figure 4). However, with time, the gravimetric soil moisture content was reduced as a result of plant competition for light, space, and dwindling moisture concentration among the plant densities. This finding concurs with those of Amaglo et al. [13] and Gadzirayi et al. [14] who showed that relatively close plant spacing resulted in taller plants because of competition for growth factors, especially light and space. These observations indicate that proper field management of soil moisture and fertilizer is necessary in order to supply plants with adequate levels of nutrients and moisture to overcome competition among the plants.

\subsection{Effect of Planting Density and Cutting Frequency on Chem-} ical Composition of Moringa Leaves. The chemical composition of moringa leaves was not affected by cutting interval or by plant density at Syferkuil except for iron and manganese content; at Ofcolaco, however, significant differences were observed mainly in terms of crude protein, phosphorus, potassium, iron, and zinc content at harvests 3 and 4 (Table 2). The reason for these findings might be that the plants were accumulating nutrients at a slower rate because of the low temperature and rainfall experienced at Ofcolaco before harvests 3 and 4 . These results are similar to those reported by Sánchez et al. [12] who observed no differences in chemical composition even at continuous harvests or in the harvesting of young leaves and tender stems. Furthermore, Nouman et al. [4], Moyo et al. [7], and Sánchez et al. [12] reported no changes in the chemical composition of moringa leaves in respect of plant density, cutting height, or cutting frequency mainly in terms of crude protein content. Relatively high temperature and rainfall were experienced at Ofcolaco during the trial, which affected the chemical composition of the moringa plant parts. A hot rainy season enhances biomass production and the plant's nutritional content. In this study, the reduction in chemical composition of the leaves might be due to the lack of nutrients in the soil, mainly nitrogen and phosphorus, at Ofcolaco relative to Syferkuil, where soil nutrients were higher and might have contributed towards high leaf nutrient content. Moringa is a fast growing tree and cutting might have led to excessive extraction of available soil nutrients for regrowth, which, without supplementation, led to a decline in chemical composition at harvests 3 and 4. However, several factors may have influenced the concentration of mineral elements in the plants, such as those in the soil, their availability to the plant, type of soil, soil $\mathrm{pH}$, stage of plant growth, and weather conditions $[12,26]$. In most of the studies where no significant changes of chemical composition were found, even under high temperature and rainfall conditions, adequate initial soil nutrients were maintained prior to planting and during growth. For example, in the study by Nouman et al. [4], there was a basal fertilizer application of 90:80:90 NPK kg/ha. Sánchez et al. [12] applied fertilizer at a rate of $90 \mathrm{~kg} \mathrm{~N} / \mathrm{ha}$ as urea, $30 \mathrm{~kg} \mathrm{P} / \mathrm{ha}$ $\left(\mathrm{P}_{2} \mathrm{O}_{5}\right)$, and $30 \mathrm{~kg} \mathrm{~K} / \mathrm{ha}\left(\mathrm{K}_{2} \mathrm{O}\right)$. Further findings by Dania et al. [25] revealed that the nutrient concentration of moringa leaves was significantly improved by treating degraded soil with poultry manure. Under high rainfall and temperature conditions, application of nutrients to the soil will improve plant growth and the chemical composition of the plants. Compared with other studies, moringa plants from this study had a satisfactory chemical composition when grown at both study sites, although some of the nutrient composition was reduced at Ofcolaco at the time of harvests 3 and 4 . This study revealed also that moringa, grown under the variable weather conditions of Limpopo at diverse plant densities, maintained a nutritional composition which can be utilized as potential supplementary feed for livestock, mainly as a protein source. Several studies have reported a similar range of protein content, from $11.4 \%$ up to $40 \%$ [4, 7, 9, 12, 27-29]. Results from this study concur with findings by Nouman et al. [11], where it was indicated that moringa is rich in nutrients like iron, potassium, calcium, and multivitamins, which are more important in weight gain and milk production.

\section{Conclusion}

Planting moringa at a relatively high density increased biomass production. A planting density of 435,000 plants/ha resulted in enhanced biomass accumulation at all cutting intervals. Low temperature and drought had a negative impact on biomass production and nutritional composition of moringa, mainly iron content. Moringa can be harvested at a height of $50 \mathrm{~cm}$ above ground level, which facilitates mechanical harvesting, and while the stem is still pliable. The crop is able to supply livestock with a satisfactory amount of crude protein, and the tree is rich in other nutrients, making it a potentially valuable source of feed supplement at times when there is not enough natural fodder due to drought. Moringa is capable of producing a good yield at a relatively high density of plants. Moreover, it is desirable to consider fertilizer application to boost plant growth and the chemical composition of the aboveground plant parts in high temperature and rainfall areas. Moringa proved to be a good source of fodder for livestock, is able to survive harsh growing conditions, and can be recommended to resource-poor smallholder farmers in regions such as Limpopo. Further studies should be conducted to evaluate the use of fertilizer under diverse weather conditions and soil types on behalf of those farmers who are willing and able to grow the plant on a larger or commercial scale. 


\section{Conflicts of Interest}

The authors declare that there are no conflicts of interest regarding the publication of this article.

\section{Acknowledgments}

The authors acknowledge the NRF-Thuthuka, NRF-RVSC, and VLIR-IUC-University of Limpopo for funding the project.

\section{References}

[1] S. A. Rankoana, "Perceptions of climate change and the potential for adaptation in a rural community in Limpopo Province, South Africa," Sustainability, vol. 8, no. 8, article no. 672, 2016.

[2] P. Maponya and S. Mpandeli, "Impact of drought on food scarcity in Limpopo Province, South Africa," African Journal of Agricultural Research, vol. 7, pp. 5270-5277, 2012.

[3] D. Brown, J. W. Ngambi, and D. Norris, "Voluntary intake and palatability indices of pedi goats fed different levels of acacia karroo leaf meal by cafeteria method," Indian Journal of Animal Research, vol. 50, no. 1, pp. 41-47, 2016.

[4] W. Nouman, M. T. Siddiqui, S. M. A. Basra, H. Farooq, M. Zubair, and T. Gull, "Biomass production and nutritional quality of Moringa oleifera as a field crop," Turkish Journal of Agriculture and Forestry, vol. 37, no. 4, pp. 410-419, 2013.

[5] N. Foidl, H. P. S. Makkar, and K. Becker, "The potential of Moringa oleifera for agricultural and industrial uses," in Proceedings of the International Workshop, What Development Potential for Moringa Products? pp. 47-67, Dar-es-Salaam, Tanzania, 2001.

[6] B. R. Tripathi and P. J. Psychas, The AFNETA alley farming training manual - Volume 1: Core course in alley farming. Alley Farming Network for Tropical Africa, International Institute of Tropical Agriculture, Ibadan, 1992.

[7] B. Moyo, P. J. Masika, A. Hugo, and V. Muchenje, "Nutritional characterization of Moringa (Moringa oleifera Lam.) leaves," African Journal of Biotechnology, vol. 10, no. 60, pp. 12925-12933, 2011.

[8] F. Anwar, S. Latif, M. Ashraf, and A. H. Gilani, "Moringa oleifera: a food plant with multiple medicinal uses," Phytotherapy Research, vol. 21, no. 1, pp. 17-25, 2007.

[9] B. Mendieta-Araica, E. Spörndly, N. Reyes-Sánchez, F. Salmerón-Miranda, and M. Halling, "Biomass production and chemical composition of Moringa oleifera under different planting densities and levels of nitrogen fertilization," Agroforestry Systems, vol. 87, no. 1, pp. 81-92, 2013.

[10] W. J. Asante, I. L. Nasare, D. Tom-Dery, K. Ochire-Boadu, and K. B. Kentil, "Nutrient composition of Moringa oleifera leaves from two agro ecological zones in Ghana," African Journal of Plant Science, vol. 8, no. 1, pp. 65-71, 2014.

[11] W. Nouman, S. M. A. Basra, M. T. Siddiqui, A. Yasmeen, T. Gull, and M. A. C. Alcayde, "Potential of Moringa oleifera L. as livestock fodder crop: a review," Turkish Journal of Agriculture and Forestry, vol. 38, no. 1, pp. 1-14, 2014.

[12] N. R. Sánchez, S. Ledin, and I. Ledin, "Biomass production and chemical composition of Moringa oleifera under different management regimes in Nicaragua," Agroforestry Systems, vol. 66, no. 3, pp. 231-242, 2006.

[13] N. K. Amaglo, G. M. Timpo, W. O. Ellis, R. N. Bennett, and N. Foidl, Effect of spacing and harvest frequency on the growth and leaf yield of moringa (Moringa oleifera Lam), a leafy vegetable crop, Moringa and other highly nutritious plant resources: Strategies, standards and markets for a better impact on nutrition in Africa. Accra, Ghana, November 16-18, 2006.

[14] C. T. Gadzirayi, S. M. Mudyiwa, J. F. Mupangwa, and J. Gotosa, "Cultivation practices and utilization of Moringa oleifera provenances by small holder farmers: case of Zimbabwe," Asian Journal of Agricultural Extension, Economics and Sociology, vol. 2, no. 2, pp. 152-162, 2013.

[15] M. Moshia, M. Mashatola, P. Shaker, P. Fouché, and M. Boshomane, "Land suitability assessment and precision farming prospects for irrigated maize-soybean intercropping in syferkuil experimental farm using geospatial information technology," Journal of Agriculture and Social Research (JASR), vol. 8, no. 2, 2009.

[16] Soil Classification Working Group, Soil Classification-a Taxonomic System for South Africa, Memoirs on the Agricultural Natural Resources of South Africa No. 15. Department of Agricultural Development, Pretoria, 1991.

[17] A. S. Dolo, Canola growth, grain and oil yield response to planting date under diverse climatic conditions in Limpopo province, MSC Dissertation, University of Limpopo. P. 15, 2016.

[18] http://www.getamap.net/maps/south_africa/limpopo/_ofcolaco/.

[19] C. A. Black, Methods of Soil Analysis: Part I Physical and Mineralogical Properties, American Society of Agronomy, Madison, Wis, USA, 1965.

[20] AOAC, Official Methods of Analysis, K. Helrick, Ed., Association of Official Analytical Chemists, Arlington, Tex, USA, 15th edition, 1990.

[21] T. P. Gaines and G. A. Mitchell, "Boron determination in plant tissue by the azomethine h method," Communications in Soil Science and Plant Analysis, vol. 10, no. 8, pp. 1099-1108, 1979.

[22] A. A. Fadiyimu, A. N. Fajemisin, J. A. Alokan, and R. D. Aladesanwa, "Effect of cutting regimes on seasonal fodder yields of Moringa oleifera in the tropical rainforest of Nigeria," Livestock Research for Rural Development, vol. 23, no. 2, 2011.

[23] M. Goss, "A study of the initial establishment of multi-purpose moringa (Moringa oleiferaLam) at various plant densities, their effect on biomass accumulation and leaf yield when grown as vegetable," African Journal of Plant Science, vol. 6, no. 3, pp. 125129, 2012.

[24] I. N. Abdullahi, K. Ochi, and A. B. Gwaram, "Plant population and fertilizer application effects on biomass productivity of Moringa oleifera in North-Central Nigeria," Peak Journal of Agricultural Sciences, vol. 1, no. 6, pp. 94-100, 2013.

[25] S. O. Dania, P. Akpansubi, and O. O. Eghagara, "Comparative effects of different fertilizer sources on the growth and nutrient content of Moringa (Moringa oleifera) seedling in a greenhouse trial," Advances in Agriculture, vol. 2014, Article ID 726313, 6 pages, 2014.

[26] M. S. Lukhele and J. B. J. Van Ryssen, "The chemical composition and potential nutritive value of the foliage of four subtropical tree species in southern Africa for ruminants," South African Journal of Animal Sciences, vol. 33, no. 2, pp. 132-141, 2003.

[27] A. B. Gidamis, J. T. Panga, S. V. Sarwatt, B. E. Chove, and N. B. Shayo, "Nutrient and antinutrient contents in raw and cooked young leaves and immature pods of Moringa Oleifera, Lam," Ecology of Food and Nutrition, vol. 42, no. 6, pp. 399-411, 2003.

[28] I. Oduro, W. O. Ellis, and D. Owusu, "Nutritional potential of two leafy vegetables: Moringa oleifera and Ipomoea batatas 
leaves," Scientific Research and Essays, vol. 3, no. 2, pp. 57-60, 2008.

[29] H. P. S. Makkar and K. Becker, "Nutrional value and antinutritional components of whole and ethanol extracted Moringa oleifera leaves," Animal Feed Science and Technology, vol. 63, no. 1-4, pp. 211-228, 1996. 


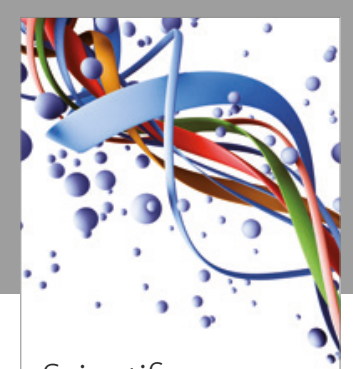

Scientifica
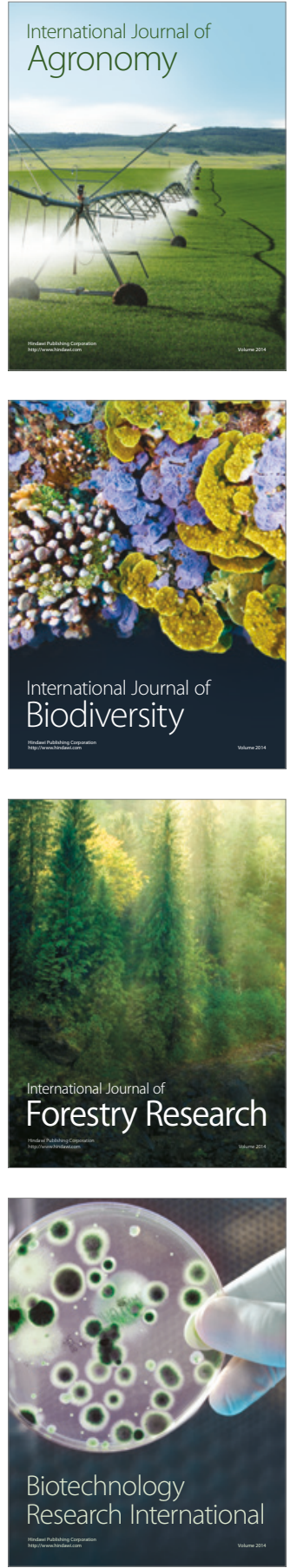
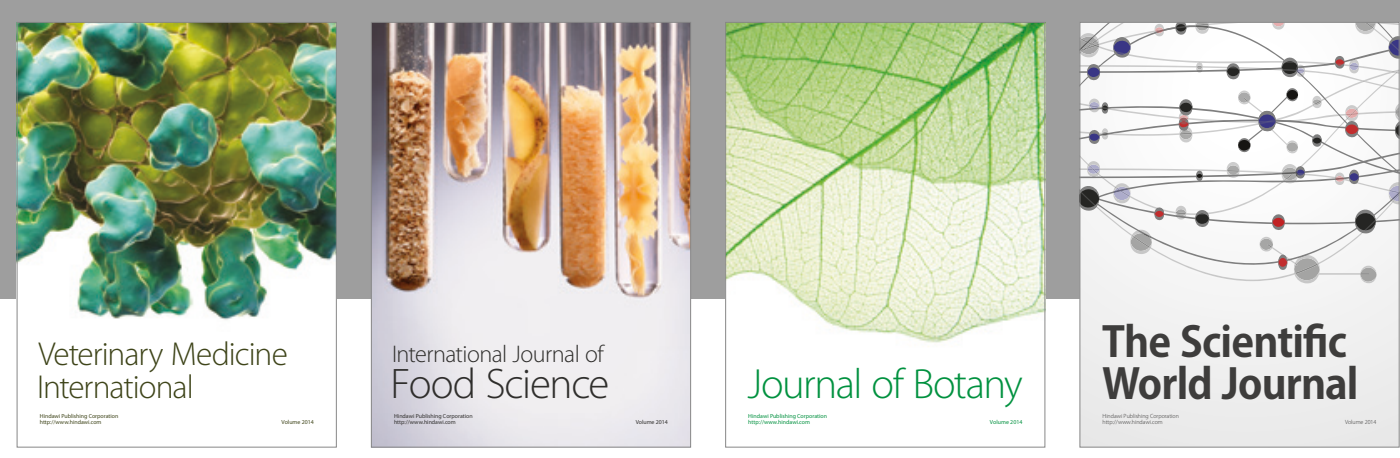

The Scientific

\section{World Journal}

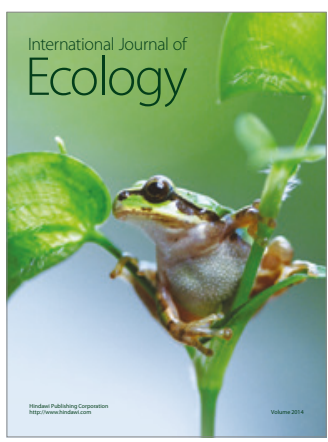

\section{Hindawi}

Submit your manuscripts at

https://www.hindawi.com
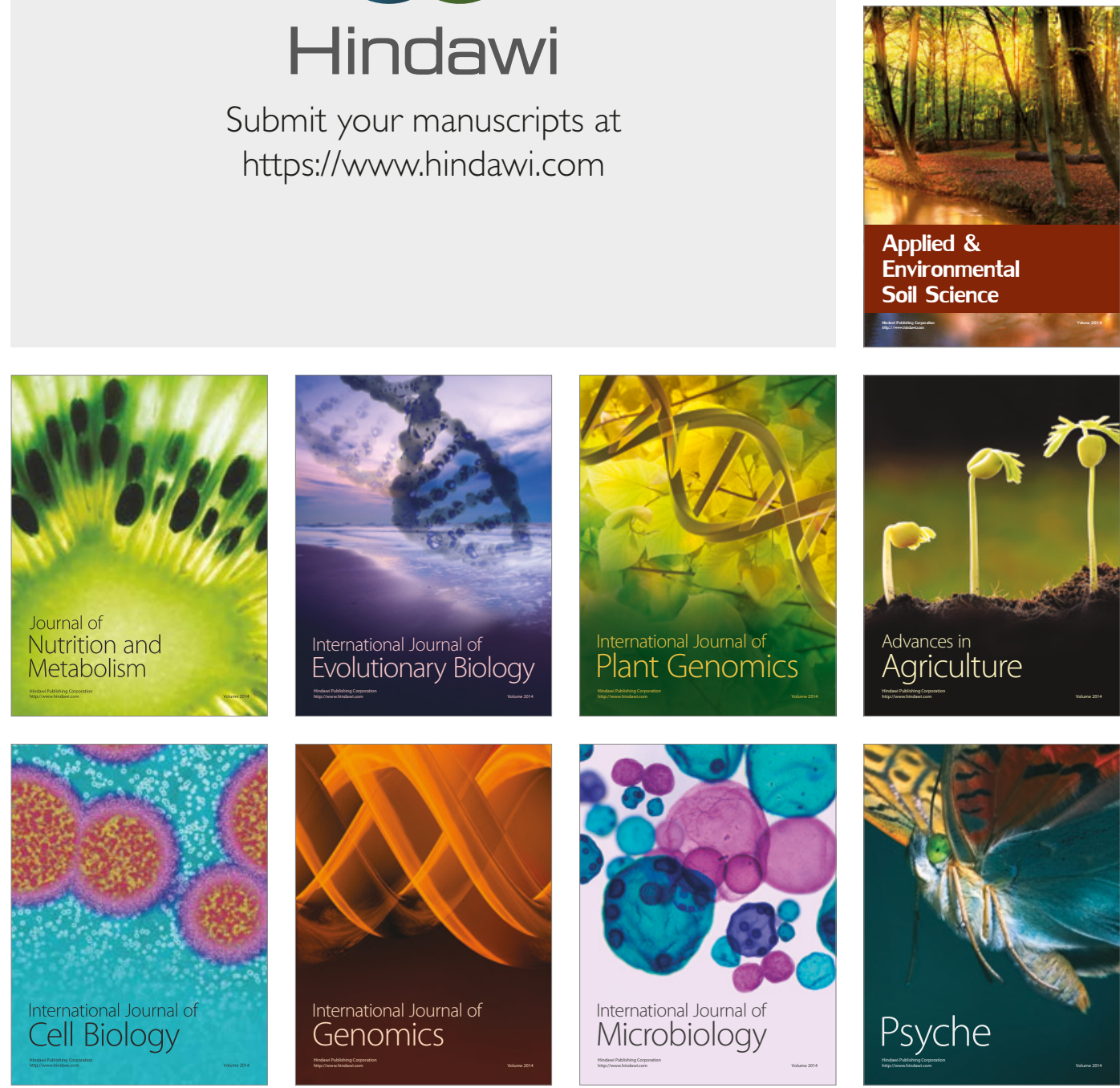

hternational Journal of Microbiology
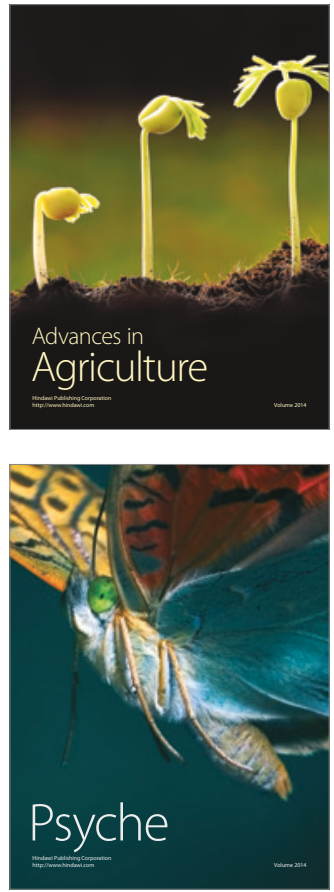